\title{
Volatiles in the Chile Ridge Basalts and the Role of Adjacent Andean Subduction Zone
}

\author{
SOUMEN MALLICK ${ }^{1}$, SOPHIE KUHL ${ }^{1}$, ALBERTO SAAL ${ }^{1}$, \\ EMILY KLEIN ${ }^{2}$, WOLFGANG BACH ${ }^{3}$ AND BRIAN \\ MONTELEONE ${ }^{4}$ \\ ${ }^{1}$ Brown University \\ ${ }^{2}$ Duke University \\ ${ }^{3}$ University of Bremen \\ ${ }^{4}$ Woods Hole Oceanographic Institution \\ Presenting Author: soumen_mallick@brown.edu
}

Volatiles $\left(\mathrm{H}_{2} \mathrm{O}, \mathrm{CO}_{2}, \mathrm{~F}, \mathrm{~S}, \mathrm{Cl}\right)$ strongly control key physical properties of the Earth's mantle, e.g. melting temperature, viscosity, seismic velocity, and therefore, volatile contents are important to understand the origin and distribution of the Earth's mantle heterogeneity. The Chile Mid-Ocean Ridge (CMOR) is one of the few places on Earth, where its southern segments have been subducting under the South America continent for the last $\sim 14$ million years forming a slab window. Therefore, the CMOR provides a unique example to understand the interaction between the Andean sub-arc mantle and CMOR mantle. In this study, we focus on characterizing the volatile budget in the MORB glasses from the southern (five) and northern (three) CMOR segments in addition to the Valdivia Fracture Zone (VFZ) that divides CMOR. Lavas from the northern ridge segments including the VFZ are characterized by D- to N-MORB $(\mathrm{Th} / \mathrm{La}<0.06)$ whereas southern segments range from $\mathrm{D}$ - to $\mathrm{E}-\mathrm{MORB}$ $(\mathrm{Th} / \mathrm{La}=0.03-0.10)$, with some unusual "arc-like" trace element compositions (low $\mathrm{Ce} / \mathrm{Pb}$-low $\mathrm{Nb} / \mathrm{U}$ )- the only example in the global MORB database. It has been suggested that the upper mantle beneath the southern segments are contaminated by the adjacent Andean arc mantle via slab window. Here we report new SIMS analysis of volatile contents for 122 CMOR glasses, which have also been characterized for major and trace element contents and $\mathrm{Sr}-\mathrm{Nd}-\mathrm{Pb}-\mathrm{Hf}$ isotope ratios. After filtering the volatile element data for shallow level processes, we find that volatile concentrations display a decent correlation with trace element contents and isotope ratios. The D- to N-MORB from the southern and northern segments including the VFZ mostly overlap in their $\mathrm{H}_{2} \mathrm{O} / \mathrm{Ce}$ (southern-107-327, northern- 151-287). Interestingly, "arc-like" E-MORB samples from the southern segments do not exhibit higher $\mathrm{H}_{2} \mathrm{O} / \mathrm{Ce}(<300$ content $)$ as would be expected if the southern segments are contaminated by the arc mantle. Instead, "arc-like" samples are extended to low $\mathrm{H}_{2} \mathrm{O} / \mathrm{Ce}(100)$ suggesting the loss of most of its $\mathrm{H}_{2} \mathrm{O}$ content due to the faster diffusion of $\mathrm{H}$ during its long storage in the mantle, as evidenced by the presence of long-lived heterogeneity (radiogenic $\mathrm{Sr}-\mathrm{Pb}$ and un-radiogenic $\mathrm{Nd}-\mathrm{Hf}$ ). 